JURNAL KETAHANAN NASIONAL

P-ISSN: 0853-9340, e-ISSN: 2527-9688

Online sejak 28 Desember 2015 di: http://jurnal.ugm.ac.id/JKN

VOLUME 22

No. 3, 27 Desember 2016

Halaman 334-353

\title{
PERAN KONSELING PANTI REHABILITASI DALAM MENANGANI PEMUDA KORBAN NARKOBA DAN IMPLIKASINYA TERHADAP KETAHANAN PRIBADI \\ (Studi Pada Panti Sosial Pamardi Putra, Sleman, Daerah Istimewa Yogyakarta)
}

\author{
Rusti Aisya Dilliana \\ Guru Sekolah Dasar Unggulan Muslimat NU \\ Email: rusti.aisya@gmail.com \\ Fathul Himam \\ Fakultas Psikologi Universitas Gadjah Mada \\ fhimam@ugm.ac.id \\ Samsul Maarif \\ Sekolah Pascasarjana Universitas Gadjah Mada \\ samsul.maarif75@ugm.ac.id
}

\begin{abstract}
Drug abuse was serious threat for Indonesia future. Yogyakarta was the city of educator from variety of districts even from abroad too, so it was susceptible from threat of drug. People in general made building the clean drug area by aspiration of society brought the victims of drug abuse to rehabilitation institution really helped. These research purposes were to knew counseling function which counselor brought to handled resident (drug user) in PSPP Yogyakarta, and tomade analysis counseling impact which counselor brought to personal resilience of drug user in PSPP Yogyakarta.

The kind of research was used qualitative research by phenomenology approach; research used depth interview, observation, literature, online, and documentation. Analysis technique used open coding and axial coding, then researcher checked by triangulation of resource data. Data analysis explained the role of counseling rehabilitation institution for handling the youth of drug victim by personal resilience implication in PSPP Yogyakarta. Research result was finding counseling role in PSPP Yogyakarta which had essential counseling function for creating comfortable and counseling function as role model. Counseling function was created from counseling factor, so it could improve resilience the youth of drug victim in PSPP Yogyakarta.
\end{abstract}

Keywords: Counseling, Drug, and Personal Resilience

\begin{abstract}
ABSTRAK
Penyalahgunaan narkoba sudah menjadi ancaman yang serius untuk Indonesia. Diketahui dari Yogyakarta, merupakan kota pelajar dari berbagai daerah bahkan luar negeri, sehingga sangat rentan ancaman narkoba. Tujuan penelitian ini adalah untuk mengetahui fungsi konseling yang dibawa oleh konselor dalam menangani pemuda
\end{abstract}


Rusti Aisya Dilliana, Fathul Himam, Samsul Maarif -- Peran Konseling Panti Rehabilitasi Dalam Menangani Pemuda Korban Narkoba Dan Implikasinya Terhadap Ketahanan Pribadi

(Studi Pada Panti Sosial Pamardi Putra, Sleman, Daerah Istimewa Yogyakarta)

korban narkoba di PSPP Yogyakarta, dan untuk menganalisis dampak konseling yang dibawa konselor terhadap ketahanan pribadi pemuda korban narkoba di PSPP Yogyakarta.

Peneliti menggunakan metode penelitian kualitatif dengan pendekatan fenomenologi, melalui wawancara yang mendalam, observasi, studi pustaka, online, dan dokumentasi. Teknik analisis yang digunakan open coding dan axial coding, kemudian menggunakan trianggulasi sumber data untuk mengecek data yang berhasil peneliti dapatkan. Hasil penelitian yang ditemukan adalah peran konseling di PSPP Yogyakarta membutuhkan fungsi konseling dalam menciptakan kenyamanan dan fungsi konseling sebagai role model. Fungsi konseling tercipta melalui faktor konseling, sehingga mampu meningkatkan ketahanan pribadi pemuda korban narkoba di PSPP Yogyakarta. Dampak dari fungsi konseling, terciptanya ketahanan pribadi yang tertanam dengan kuat, agar mampu menghadapi tekanan lingkungan sosial dengan tangguh.

\section{Kata Kunci: Konseling, Narkoba, dan Ketahanan Pribadi}

\section{PENGANTAR}

Penelitian ini menganalisis tentang peran konseling panti rehabilitasi dalam menangani pemuda korban narkoba dan implikasinya terhadap ketahanan pribadi. Narkoba telah menjadi ancaman yang serius untuk Indonesia, hingga Indonesia ditetapkan sebagai kawasan darurat narkoba (BNN RI, 2015). Yogyakarta yang sering disebut sebagai Kota Pelajar, yang di dalamnya terdiri dari berbagai daerah dan bahkan luar negeri. Hal ini yang membuat rentan dengan narkoba, diketahui pengguna narkoba di Yogyakarta yang meningkat setiap tahunnya. Menurut Oetami (2014), pengguna narkoba tahun 2004 berjumlah 57.453 orang, tahun 2008 berjumlah 68.980 orang, dan tahun 2011 meningkat menjadi 69.700 orang.

Diketahui melalui penelitian dari Universitas Indonesia di sepuluh kota terbesar di Indonesia mempunyai kebutuhan 1,7 ton ekstasi dan 0,5 ton kokain setiap tahunnya. Pengawasan optimalpun dibuat pada UU yang terkini yakni UU No. 35 Tahun 2009. Dalam UU ini lebih lengkap, menjelaskan narkotika adalah zat atau obat yang berasal dari tanaman atau bukan tanaman baik sintesis atau semi sintesis yang dapat menyebabkan penurunan atau perubahan kesadaran, hilangnya rasa nyeri dan dapat menimbulkan ketergantungan. Penekanan UU ini merupakan upaya pencegahan, pemberdayaan masyarakat, upaya pemberantasan tindak pidana narkotika, dan kewajiban rehabilitasi untuk pecandu (Oetami, 2014).

Masalah narkoba ini sangat mengancam Indonesia salah satunya adalah Kota Yogyakarta. Dampak dari narkoba ini dapat menyebabkan korban jiwa dan bermasalah dengan hukum, hingga banyak iklan layanan masyarakat yang berharap korban penyalahgunaan narkoba mampu melapor ke Institusi Penerima Wajib Lapor (IPWL) atau BNN. IPWL dibuat agar mampu melahirkan kawasan bebas narkoba, sedangkan Badan Narkotika Nasional (BNN) mempunyai program P4GN. Rina BNN DIY mengungkapkan bahwa, Program Pencegahan dan Penanggulangan terhadap Penyalahgunaan dan Peredaran Gelap Narkotika (P4GN) yang dibuat BNN memberikan kemudahanan bagi korban penyalahgunaan narkoba, karena korban diperbolehkan untuk rawat jalan. Kenyataan yang terjadi adalah sebagus apapun program yang diberikan oleh pemerintah, tidak membuat korban penyalahgunaan narkoba tergugah untuk melaporkan keadaan dirinya.

Tingkat pendidikan masyarakat dan supremasi hukum adalah beberapa faktor pendorong maraknya narkoba. Faktor pendorong ini ternyata sangat berpeluang 
Gambar 1

Jumlah kasus narkoba di DIY tahun 2008-2014 (Januari - Juli)

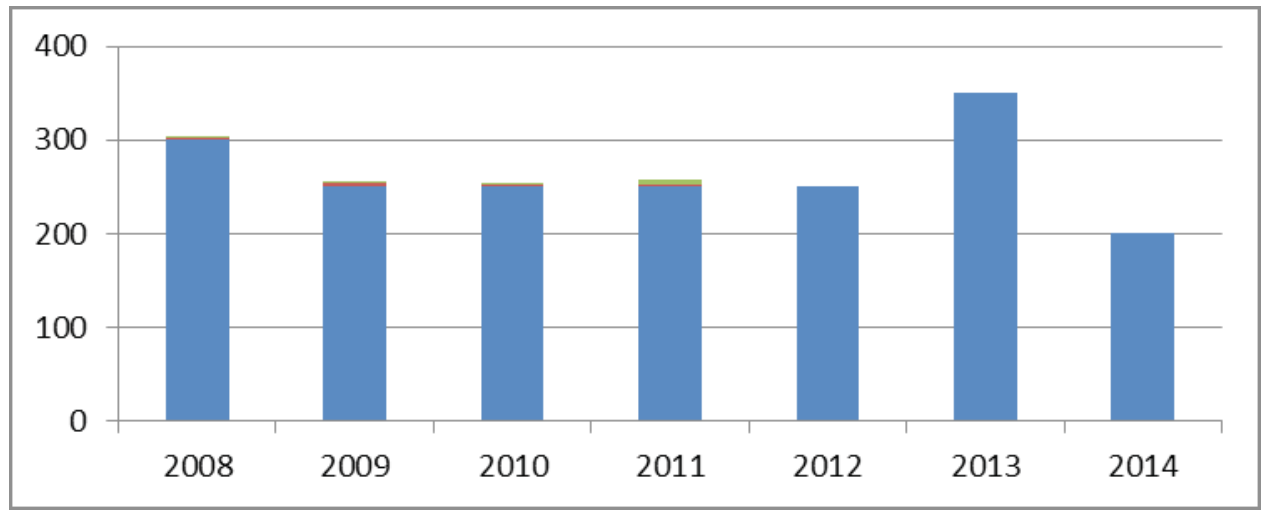

Sumber: Oetami 2014

besar yakni di Kota Yogyakarta yang terkenal dengan sebutan Kota Pelajar. Ini juga ditunjang dengan keadaan kemiskinan, utang piutang, rendahnya kontrol sosial, dan stigmatisasi. Menurut data Badan Pusat Statistik (BPS) Yogyakarta, Kota Yogyakarta tergolong dengan masyarakat yang selalu berbahagia walaupun dominan Kota Yogyakarta adalah ekonomi rendah. Banyak dari mereka berprinsip "nrimo" namun hal ini ternyata menjadi peluang untuk penyebaran agen narkoba di beberapa titik di Yogyakarta, para agen lebih fokus menyalurkan sasaran narkoba kepada pelajar atau mahasiswa. Menurut laporan dari BNN DIY tahun 2014, jumlah pengungkapan kasus narkoba di DIY sangat fluktualitif setiap tahunnya, sebagaimana gambar 1 .

Gambar (grafik) 1 tersebut menjelaskan peningkatan kasus narkoba yang mengalami peningkatan lebih fluktualitas (tidak tetap kenaikannya). Hal ini tetap menjadi masalah yang kongkret dan komplek karena berpengaruh di berbagai aspek. Terlihat terjadinya penurunan kasus yang lumayan baik pada tahun 2013 hingga 2014. Diketahui pada tahun tersebut pemerintah sudah mampu bekerja dengan baik, sehingga diharapkan pemerintah (IPWL) dan BNN mampu bekerja keras lagi untuk mensosialisasikan P4GN dari dampak, pengaruh, dan proses penanggulangan meluasnya korban penyalahgunaan narkoba.

Konsep ideal yang diberikan oleh pemerintah untuk para pecandu narkoba adalah berupa sarana rehabilitasi yang diharapkan memulihkan generasi Indonesia. PSPP Yogyakarta merupakan tempat rehabilitasi yang melakukan penyembuhan dari sisi medis dan sosial, cara berkomunikasinya dibantu dengan konselor. Konselor yang mampu membantu residen (pecandu narkoba) untuk efektif, kognitif, mampu memotivasi, dan membuat strategi sikap untuk mampu diterima di masyarakat (Stea, 2015). Kemampuan konselor tersebut sangat bermanfaat untuk menghadapi residen dari keadaan fisik, psikis, dan mood yang harus selalu dijaga baik nyamannya dan kesehatannya. Konselor dalam hal ini harus menunjukkan perhatian secara penuh kepada konseli (informan), ini digunakan dalam mengawali wawancara konseling. Dalam proses konseling ini konselor harus mempersiapkan konseli (informan) untuk terlibat dalam konseling (Muhdi, 2011). Konselor yang berhasil melakukan wawancara 
Rusti Aisya Dilliana, Fathul Himam, Samsul Maarif -- Peran Konseling Panti Rehabilitasi Dalam Menangani Pemuda Korban Narkoba Dan Implikasinya Terhadap Ketahanan Pribadi (Studi Pada Panti Sosial Pamardi Putra, Sleman, Daerah Istimewa Yogyakarta)

awal akan mempermudah konseling selanjutnya. Proses konseling ini dilakukan secara informal, konselor hendaknya aktif, dan menerima residen sebagai seorang manusia yang berharkat dan bernilai.

Amal (1999) menyatakan bahwa ketahanan nasional diartikan sebagai kemampuan dan kemauan yang ulet dan cerdas dari masyarakat untuk menghadapi ancaman, tantangan, hambatan, dan kesempatan. Hal ini sangatlah dipengaruhi induvidu atau warga negara yang mempunyai kekuatan, sikap, dan kemampuan untuk menghadapi tantangan. Ketahanan pribadi ini merupakan dasar dari ketahanan nasional. Pribadi residen yang mampu mempunyai ketahanan pribadi yang mantap jika didukung dengan lingkungannya, mampu melahirkan lingkungan rehabilitasi yang mampu menjadikan masyarakatnya maju. Lingkungan yang mampu menjadikan masyarakatnya maju, yaitu yang mampu membentuk kepentingan bersama untuk digunakan dalam keadaan saling memotivasi untuk hidup lebih baik di masa depan. Mimpi yang tertunda akan mampu diraih dengan keuletan dan ketangguhan, sikap ini akan membangkitkan pada rasa percaya pada kekuatan sendiri (Sunardi, 2005). Peran konseling sangat diperlukan dalam membina residen berpikir positif dan konselor juga harus mempunyai strategi khusus yang menyentuh hati dan pikiran residen melalui jalur pembinaan lingkungan pergaulan. Tujuan untuk menjadikan residen clean drug dan pulih dari kondisinya, sehingga mampu menjadi generasi muda bangsa yang berkualitas.

Berdasarkan uraian pengantar tersebut, peneliti menetukan beberapa permasalahan penelitian, yaitu: Pertama, bagaimana peran konseling yang dilakukan konselor panti rehabilitasi dalam menangani pemuda korban narkoba pada Panti Sosial Pamardi Putra Yogyakarta? Kedua, faktor-faktor konseling apakah yang berperan dalam meningkatkan ketahanan pribadi pemuda korban narkoba pada Panti Sosial Pamardi Putra Yogyakarta? Ketiga, bagaimana implikasi peran konseling terhadap peningkatan ketahanan pribadi pemuda korban narkoba pada Panti Sosial Pamardi Putra Yogyakarta?

Beberapa teori yang dijadikan sebagai pisau analisis dalam penelitian ini adalah sebagai berikut.

Pertama, teori konseling. Liliweri (2003), peran adalah sebuah harapan budaya terhadap suatu posisi atau kedudukan. Peran lebih dikaitkan harapan pada perilaku aktual yang akan dilakukan. Perilaku aktual yang dilahirkan dari keinginan membantu orang dengan menciptakan hubungan yang bebas dan berstruktur yang membiarkan klien memperoleh pengertian sendiri untuk melakukan langkah positif ke arah orientasi baru merupakan proses konseling (Gunarsa, 2007). Tujuan yang diharapkan dari proses konseling ini adalah untuk membuat kondisi yang memudahkan terjadinya perubahan baik pada diri pecandu narkoba.

Menguasai lingkungan dengan konseling yang berkomitmen terhadap etika professional, dengan respon positif dari konselor terhadap konseling akan menciptakan rasa kenyamanan dan ketenangan dalam diri residen. Menurut Supriatna (2013), konselor adalah tenaga professional yang memiliki sertifikasi dan lisensi untuk menyelenggarakan layanan profesionalnya. Menjadi seorang konselor harus professional dengan rancangan menggunakan peluang (yakni mengenal perkembangan, masalah, dan perilaku residen), 
dukungan (upaya nyata yang dibuat untuk membangun komunikasi dengan residen), dan penghargaan (penilaian dan pemberian baik untuk menguatkan perilaku baik residen).

Tritmen yang dimunculkan oleh konselor seperti konseling, terapi kognitif, dan terapi sosial (Ali, 2007). Dengan terapi ini tingkah laku residen dapat terkontrol dengan baik, karena adiksi akan mempengaruhi perilaku residen untuk menggunakan terus menerus narkoba dan akan sulit untuk terkontrol. Harapannya tritmen ini dapat berjalan dengan baik, tanpa kekerasan. Ini dikarenakan residen akan mudah kambuh jika diberikan kekerasan, karena akan terjadi fenomena yang sulit diatasi. Uraian ini menyimpulkan layanan seorang konselor narkoba dalam membentuk mental residen yang disiplin dan mampu menyelesaikan masalahnya sendiri dengan pemikiran yang terbuka bukanlah sesuatu yang mudah. Komunikasi yang mendukung dan pemberian penghargaan konselor untuk seorang residen sangat berarti dalam sebuah interaksi.

Konselor dapat diartikan siapapun yang memberi individu suatu nasihat yang diperlukan, konsultasi, arah, dan bantuan dalam usaha mencapai tujuan tertentu. Seorang konselor bukan hanya berasal dari psikolog atau mentor, namun bisa rekan kerja, karyawan kunci, penasehat, pasangan hidup, teman, bahkan seorang pengarang. Seorang konselor ini mampu memberikan pemikiran berupa saran, kebijaksanaan, atau bantuan praktis apapun yang diperlukan untuk mencapai proyek, tujuan, atau impian spesifik secara efektif.

Menurut Arief (2008), menyatakan bahwa langkah dalam proses konseling kepada residen diawali dengan membantu residen memahami dan menyadari masalah yang dihadapi, proses ini juga membantu memahami potensi dan kekuatan residen, pembimbingan juga dilakukan pada proses ini untuk menunjukkan dan memberikan cara alternatif dalam pemecahan masalah residen. Menurut Bro Eko di Rehabsos mengatakan berita dari Depsos bahwa, perbandingan ideal dari konselor dan residen adalah 1:5. Jika terjadi penambahan residen di Rehabsos dan tidak sesuai dengan perbandingan yang diberikan oleh Depsos, maka diperlukan rekrutmen konselor addict dari anak binaan di Rehabsos tersebut dan rehabsos yang lain. Konselor addict yang lahir melalui pengalamannya menggunakan narkoba, akan diminta kerelaan hatinya untuk berbagi ilmu dengan residen yang lain. Ilmu yang ditularkan, rasa sakit yang dirasakan, dan frustasi terhadap masalah akan mampu dicari titik terang. Residen di sini akan dibina untuk melahirkan solusi dari masalahnya sendiri. Uraian tersebut mengisyaratkan betapa pentingnya peran konselor dalam perawatan dan penanganan rehabilitasi residen. Konselor yang terdiri dari konselor statik, konselor senior, konselor adiksi, dan konselor yang lahir dari pekerja sosial (peksos).

Konselor dalam konseling Islam berperan sebagai guru, mitra/sahabat bertukar pikiran, orang tua dan model (Diniaty, 2013). Dalam hal ini tujuan konseling adalah pengembalian iman sebagai penentu kebahagian dunia. Memahami tehnik dan pendekatan konseling harus melalui pemahaman spiritual yang tertanam dalam diri. Dasar pemahaman yang harus ditanamkan kepada residen (pecandu narkoba) adalah Tuhan tidaklah pernah membebani individu, semua diberikan sesuai kemampuan manusia dan dibaliknya terdapat hikmah. 
Rusti Aisya Dilliana, Fathul Himam, Samsul Maarif -- Peran Konseling Panti Rehabilitasi Dalam Menangani Pemuda Korban Narkoba Dan Implikasinya Terhadap Ketahanan Pribadi (Studi Pada Panti Sosial Pamardi Putra, Sleman, Daerah Istimewa Yogyakarta)

Seseorang yang rendah efikasi diri (low self-efficacy) akan merasa pasrah, apatis, pesimis, cemas, merasa tidak mampu, dan tidak yakin terhadap kemampuan. Permasalahan ini biasanya terjadi pada pemuda korban penyalahgunaan narkoba yang tidak menggunakan narkoba pada waktu itu. Menurut Humeira (2014), Pelaksanaan layanan konseling dapat digunakan untuk meningkatkan efikasi diri (self-efficacy) dengan menggunakan teknik problem solving. Residen dalam perawatan dan penanganan rehabilitasi diharapkan mampu belajar untuk beradaptasi melupakan narkoba. Proses konseling yang diberikan kepada residen mampu memecahkan masalah residen yang rindu narkoba dengan meningkatkan efikasi diri.

Konselor narkoba harus mampu bertemu dengan pemuda korban narkoba secara intensif di tempat rehabilitasi. Menurut Joewana (2006), residen yang direhabilitasi harus mendapatkan penanganan rehabilitasi fisik, mental, spiritual, edukasional, dan vokasional. Konselor membantu para residen untuk melakukan detoksifikasi racun dari narkoba, hal ini dilakukan untuk memulihkan kesehatan residen. Nilai spiritual juga harus didapatkan oleh residen melalui pendalaman iman menurut keyakinannya masing-masing. Keterampilan pun diberikan untuk residen sebagai bekalnya untuk mandiri dan menjalani hidup lebih baik. Berbagai pendidikan bermanfaat dalam terapi harus mampu residen serap, residen akan dibimbing oleh konselor untuk membangun mentalnya untuk mampu menyelesaikan masalahnya dengan pemikiran yang lapang.

Proses konseling biasanya terkendala dengan kesenjangan-kesenjangan dalam relasi konselor-klien (Yeo, 2007). Dalam beberapa situasi konselor mengalami kesulitan dalam kesenjangan antara yang harus konselor lakukan sebagai konselor dan dengan apa yang senyatanya konselor alami. Dalam buku Yeo menjelaskan beberapa hal yang akan terjadi ketika konselor berinteraksi dengan klien, yaitu (1) Membuka diri, dalam hal ini biasanya klien meminta konselor mampu membuka dirinya juga kepada klien, (2) Perasaanperasaan konselor terhadap klien, hal yang terjadi ketika perasaan amarah yang muncul ketika menghadapi klien. Di sini konselor diharapkan mampu memahami, menerima klien, dan bersikap sabar dengan klien. (3) Daya Tarik Seksual, hal ini disinggung karena melihat dari proses konseling sendiri yang melibatkan hubungan persaan dua orang atau lebih. (4) Ditantang Klien, di sini klien mampu menantang kehandalan konselor melalui bahasanya atau dalam bentuk apapun. Hal ini biasa terjadi ketika akan melakukan perjanjian konseling dengan konselor.

Uraian ini menyimpulkan berbagai hal yang terjadi nyata dalam interaksi konselor dengan klien. Konselor dalam hal ini diharapkan mempunyai kesabaran yang tinggi dan mampu mengontrol hati. Kebijaksanaan konselor akan membawa residen pada pribadi yang kuat, pandai bersyukur, dan lebih dekat kepada Sang Pencipta.

Kedua, narkoba. Narkoba adalah zat atau obat yang dapat merusak sistem kerja saraf manusia, jika mengkonsumsinya secara terus menerus. Mengingat narkoba merupakan zat yang menimbulkan bahaya ketergantungan dan kematian. narkoba diatur dalam UU Nomor 35 Tahun 2009 Tentang Narkotika dan UU Nomor 5 Tahun 1997 Tentang Psikotropika.

Menurut Ali (2007), hal ini yang menyebabkan berlakunya pepatah mengobati 
lebih baik ketimbang membiarkannya berlarut-larut. Perkembangan narkoba yang telah memprihatinkan ini membutuhkan penanganan yang komprehensif. Pemilihan rujukan keluarga untuk masuk ke tempat rehabilitasi adalah solusi tepat agar kesehatan mampu diraih dan mampu hidup lebih baik.

Pemerintah pusat maupun daerah telah menerbitkan hukum yang diarahkan kepada upaya mensejahterakan masyarakat, dari undang-undang sampai dengan peraturan gubernur. Dalam konteks DI Yogyakarta, PSPP DI Yogyakarta membuat hirarkhi sebanyak 10 produk hukum (PSPP DIY, 2015) . Dasar-dasar hukum ini yang telah dijabarkan merupakan kekuatan pemerintah untuk merubah moral generasi Indonesia. Hal yang sering disebut sebagai revolusi mental ini, diharapkan mampu menanggulangi korban penyalahgunaan narkoba. Jeratan narkoba yang menyiksa diharapkan mampu menjadi pelajaran untuk residen agar mampu merubah dirinya menjadi lebih baik. Rasa sakit yang tidak tertahankan, banyaknya kejadian yang menimpa residen tanpa residen ketahui ketika menggunakan narkoba. Berbagai hal yang merugikan orang lain hingga membuat residen hanya mampu menyesal di panti rehabilitasi yang penuh aturan.

Rehabilitasi yang dilakukan di panti rehabilitasi biasanya menggunakan metode Theurapeutic Community (TC) dan terdapat 4 fokus pembinaan, yaitu perubahan perilaku, penataan emosi dan psikologi, peningkatan bidang spiritual dan intelektual, dan kemampuan bertahan hidup dan kemandirian. Menurut PSPP DIY, proses yang dilakukan dalam rehabilitasi adalah sebagai berikut

Pertama, tahap penerimaan. Pada tahap ini akan dilakukan wawancara awal, proses assesment, mengisi form perjanjian, pemeriksaan pakaian, dan peralatan pribadi, pemeriksaan fisik dan kesehatan. Hal ini dilakukan oleh residen baru pada umumnya.

Kedua, tahap detoksifikasi. Tahap detoksifikasi ini dilakukan selama 1-2 minggu untuk membersikan racun dalam tubuh residen dan mengantisipasi terjadinya withdrawal syndrome.

Ketiga, tahap pemulihan awal (Entry Unit). Pemulihan awal 2-3 minggu setelah detoksifikasi dan mempersiapkan diri sebelum masuk ke perawatan utama.

Keempat, Tahap Rawatan Utama (Primary Stage). Pada tahapan Primary ini akan dilaksanakan selama 6-9 bulan, biasanya tahapan ini menyesuaikan perkembangan residen, dengan menempuh 4 fase, yaitu:(a.) Fase Introduction, (b.) Fase Younger Member, (c.) Fase Middle Peer, (d). Fase Older Member.

Kelima, tahap resosialisasi (The Entry Stage). Pada tahap Resosialisasi ini residen memerlukan waktu selama 6-9 bulan merupakan tahap pemulihan diri, tanggung jawab diri, dan psikologis dalam dirinya untuk berinteraksi dengan keluarga dan masyarakat, tergantung perkembangan residen, dengan menempuh 4 fase, yaitu Fase Orientasi, Fase A, Fase B, dan Fase C

Keenam, tahap pembinaan lanjut dan terminasi (After Care Stage). Tahapan ini merupakan tahapan terakhir dari perawatan dan penanganan di rehabilitasi, residen diharapkan sudah mampu mandiri dan mempunyai ketahanan pribadi yang cukup agar tidak relaps kembali. Di sini konselor memastikan residen yang telah sembuh mempunyai lingkungan yang sehat dan mengerti akan dirinya.

Kesimpulannya adalah narkoba merupakan suatu bahan yang berbahaya dan 
Rusti Aisya Dilliana, Fathul Himam, Samsul Maarif -- Peran Konseling Panti Rehabilitasi Dalam Menangani Pemuda Korban Narkoba Dan Implikasinya Terhadap Ketahanan Pribadi (Studi Pada Panti Sosial Pamardi Putra, Sleman, Daerah Istimewa Yogyakarta)

dilarang keberadaannya baik diproduksi, dipasok, dan digunakan. Penanganan narkoba dapat dilakukan melalui strategi nasional P4GN yang mengarah lebih pada pencegahannya dan rehabilitasi yang lebih mengarah pada pengobatannya.

Narkoba digunakan untuk keperluan medis dan studi ilmiah, namun ternyata banyak yang menyalahgunakan pemakaian narkoba hingga kecanduan untuk menggunakannya. Penggunaannya ini mampu menjadi berbahaya dikarenakan tidak mengetahui takaran medisnya dan dosisnya. Hal ini yang menjadikan narkotika menjadi dilarang penggunaannya.

Menurut Al-Ghifari (2002), pecandu narkoba kebanyakan ditemukan berusia sekitar SLTP dan SLTA. Diketahui hal ini dipicu oleh proses transisi para remaja, yang biasanya diakibatkan oleh minimnya perhatian orang tua. Penyalahgunaan narkoba pun tidak segan untuk menyakiti orang disekitarnya, seperti pengakuan Rama (Residen PSPP DIY).

Saya bukan hanya menggunakan sabu-sabu, tapi saya juga menjualnya, karena saya terkadang tidak mempunyai uang jajan berlebih. Saya biasanya menjual sabusabu 1 gramnya sekitar 1,3 juta. Terkadang perekonomian teman turun saya bagi sabu itu 1 gram menjadi 6 sabu. Hal curang itu, saya lakukan agar saya mendapatkan uang berlebih untuk membeli sabu kembali (Wawancara Rama pada 25 November 2015).

Pengakuan Hilman dalam buku AlGhifari (2002), Hilman mengatakan demi putau hilman siap merampok dan membobol uang orang tuanya. Menurutnya kenikmatan putau yang lima kali lebih nikmat dari heroin, keadaan uang yang menipis membuatnya dijauhi teman-temannya. Temannya mengetahui bahwa Hilman sudah mulai kecanduan, hilman pun terkadang nekad untuk membobol uang ibunda sebesar 10 juta. Hilman menghabiskannya dalam waktu 1 minggu

Sindikat pengedar ganja di Indonesia semua dimulai dari Aceh, karena diketahui Aceh merupakan penghasil ganja terbaik didunia. Bisnis ganja ini telah memberikan keuntungan besar untuk pembisnisnya di Aceh. Jalur edar setelah Aceh biasanya adalah Medan dan Jakarta, suatu daerah transportasi mudah dan terdekat dari Aceh. Daerah tersebut kemudian akan memasarkan ke daerah yang mempunyai penduduk terbesar dan kotanya besar. Surabaya, Bandar Lampung, Bandung, Batam, Bali Pontianak menjadi target pemasaran. Sesampainya ganja di Batam bisa dialirkan juga sampai ke Singapura (negara tetangga dari Indonesia).

Pemasaran heroin ini sangat menggiurkan, dalam pengakuan salah satu residen yang bernama Hilman mengatakan, kenikmatan heroin $5 \mathrm{x}$ dari shabu-shabu dan ganja. Pemasaran heroin juga pasti dimulai dari luar negeri, yaitu dari Negara yang sudah satu kelompok pengedaran atau yang disebut Bulan Sabit Emas. Analisis yang dilakukan peneliti, bahwa Bangkok yang bertugas untuk mengedarkan heroin ke Indonesia.

Penyalahgunaan terhadap shabu-shabu ini sangatlah mudah di Indonesia. Shabu-shabu di Indonesia dengan mudah didapatkan didaerah terpencil seperti Kalimantan, dll. Kebanyakan dari informan mampu mendapatkan shabushabu gratis, hanya dengan modal tolong menolong, biasanya yang memberi meminta seseorang untuk membelikan shabu-shabu penyelundupan. Seseorang yang dimintai 
tersebut, kemudian dibayar menggunakan shabu-shabu dan minuman keras.

Diketahui Indonesia yang tadinya hanya menjadi kawasan transit, namun berjalannya waktu di Indonesia mampu menjadi pemasar dan menjadi produsen. Upaya penegakkan hukum terhadap kejahatan narkoba di Indonesia yang dikeluhkan adalah berupa sanksi hukuman yang sangat ringan. Bisnis narkoba yang sangat menggiurkan di Indonesia telah menarik banyak pemasok narkoba tersebut.. Kesimpulan dari uraian ini adalah Indonesia harus mempunyai benteng yang kokoh untuk melawan pengedaran narkoba, hal itu dimulai dari pencegahan melalui strategi nasional untuk memberikan informasi yang lengkap tentang narkoba.

Ketiga, teori ketahanan pribadi. Mengembangkan resiliensi merupakan perjalanan pribadi tiap individu untuk mampu menyikapi kondisi kehidupan dengan positif (Oktaviana, 2013). Setiap Individu mempunyai persepsi hidup yang berbeda dalam peristiwa traumatik dan peristiwa hidup yang penuh perjuangan menghadapi masalah. Dalam mengatasi masalah harus mempunyai daya tahan mental yang kuat dengan cara-cara yang positif.

Menurut DeLamater (2006), Locus of Control adalah keyakinan seseorang untuk mengonsep pengendalian rasa yang terdapat dari luar dan dalam dirinya. Banyak orang yang bersikap aneh atau mengasingkan dirinya, karena tidak mampu mengontrol takdir yang terjadi pada dirinya. Sikap ini harus mampu dirubah oleh setiap manusia, di sini manusia harus mampu menjadi pemimpin atau penentu dari nasib yang dimilikinya. Ketahanan pribadi mampu membentuk sikap siap menyeleksi setiap pengaruh yang datang. Pengembangan ketahanan pribadi dengan berlandaskan Pancasila sebagai sosok manusia Indonesia implikasinya mampu memiliki watak baik yang mampu diandalkan (excellent of character), memegang prinsip dan fokus produktif untuk menjauhi narkoba (accomplish a mission). Posisi ketahanan pribadi dalam hirarki ketahanan nasional tampak pada gambar 2 sebagai berikut.

Gambar 2

Posisi Ketahanan Pribadi dalam Hirarki Ketahanan Nasional

Ketahanan Nasional

Ketahanan Daerah Ketahanan Lingkungan Ketahanan Keluarga Ketahanan Pribadi

Sumber : Soedarsono, 1997

Ketahanan pribadi ini akan berimbas kepada ketahanan nasional yang diwujudkan dengan rasa harmonis antara korban penyalahgunaan narkoba dan masyarakat. Pandangan positif tentang "say no to drug", akan membentuk Negara yang memiliki masyarakat yang bersikap tangguh. Menurut Sunardi (2005), komponen dari ketahanan nasional adalah sikap tangguh masyarakat di suatu negara, sikap tangguh tersebut mencakup keuletan dan kekuatan. Sikap pemuda korban narkoba yang ulet akan mampu bertahan hidup dalam keadaan yang sangat menantang, hingga pemuda tersebut dikatakan "clean”.

Kerangkapenelitian yang telah dituangkan dalam bagian sebelumnya mengarahkan peneliti untuk mendeskripsikan menggunakan 
Rusti Aisya Dilliana, Fathul Himam, Samsul Maarif -- Peran Konseling Panti Rehabilitasi Dalam Menangani Pemuda Korban Narkoba Dan Implikasinya Terhadap Ketahanan Pribadi (Studi Pada Panti Sosial Pamardi Putra, Sleman, Daerah Istimewa Yogyakarta)

pendekatan masalah. Metode kualitatif diharapkan mampu melakukan pendekatan kepada subjek dan objek penelitian, sehingga mampu menangkap hal-hal yang sensitif. Menurut Creswell (2013), penelitian kualitatif mempresentasikan corak eksplorasi ilmu sosial dan humaniora yang absah, tanpa harus dibandingkan dengan riset kuantitatif. Di sini peneliti mampu menjadi instrument utama untuk mengumpulkan data berupa data dan gambar. Data yang telah diperoleh bisa dianalisis secara induktif, dengan berfokus terhadap pemaknaan partisipan dan mampu dituangkan dengan bahasa yang ekspresif.

Kualitatif ini akan sangat membantu memahami detail masalah, detail tersebut bisa didapatkan melalui orang yang bersangkutan secara langsung. Strategi pendekatan yang digunakan untuk penelitian peran konselor panti rehabilitasi terhadap korban penyalahgunaan narkoba ini adalah strategi fenomenologi. Strategi fenomenologi ini merupakan strategi penelitian yang didalamnya peneliti mengidentifikasi hakikat manusia tentang suatu fenomena tertentu (Creswell, 2009). Dalam strategi ini diharapkan peneliti mampu mengkaji sejumlah subjek yang terlibat langsung dalam waktu lama untuk mengembangkan pola dan relasi makna.

Menurut Afdjani (2010), pendekatan fenomenologi ini mengajarkan untuk mempelajari bentuk pengalaman orang dari sudut pandang orang yang mengalaminya secara langsung, hingga peneliti seolah mengalaminya juga. Sumber data pendekatan fenomenologi ini dari bagaimana seseorang memaknai obyek dalam pengalamannya. Peneliti diharapkan mampu mengklasifikasikan setiap tindakan sadar yang informan atau residen lakukan, dan juga meliputi prediksi apa yang akan terjadi melalui ekspresi dari informan atau residen. Makna yang ditangkap dari fenomenologi ini lebih luas dari sekedar bahasa yang mewakili.

Letak lokasi penelitian berada di Kota Yogyakarta, yang bertempat di rehabilitasi Panti Sosial Permadi Putra (PSPP) Yogyakarta. PSPP Yogyakarta ini adalah tempat rehabilitasi yang diteliti, beralamat di Karangmojo, Purwomartani, Kalasan, Sleman, Yogyakarta, email: pantisosialpermardiputra@yahoo. com, telp. (0274)498141. Tempat rehabilitasi ini, tepatnya berada di belakang Balai Besar Pendidikan dan Pelatihan Kesejahteraan Sosial Yogyakarta.

Penelitian ini menggunakan beberapa metode dalam mengumpulkan data, yaitu wawancara mendalam, observasi, studi pustaka, online, dan dokumentasi. Metode pengumpulan data fenomenologi adalah observing, interviewing, dokumen, dan analisis (Creswell, 2013). Ini merupakan cara sederhana yang dilakukan oleh peneliti. Observing adalah melakukan pengamatan dari partisipan sampai non-partisipan.

Interviewing sering disebut sebagai wawancara yang dilakukan melalui pertanyaan tertutup hingga pertanyaan terbuka, di sini diharapkan peneliti sabar untuk menjadi pendengar, bahkan diharapkan oleh konselor senior, bahwa peneliti diharapkan bersedia belajar untuk menjadi seorang konselor melalui pelatihan dari konselor senior agar mampu memahami residen. Wawancara mendalam adalah cara yang digunakan untuk menambah informasi dan memahami induvidu sesuai dengan topik atau tema yang diteliti (Hesse, 2010). Metode pengumpulan data ini dilakukan melalui pertanyaan yang terkait dengan topik penelitian yang melibatkan 
proses interaktif informal dan menggunakan komentar (open-ended question). Terdapat tiga rangkaian wawancara: (1) cerita kehidupan (latar belakang atau sejarah), (2) pengalaman lengkap, (3) refleksi makna dari cerita. Dalam hal ini informan diberikan pertanyaan terbuka untuk menceritakan dirinya masa lalu hingga masa sekarang sesuai topik terhangat untuk penelitian.

Pengumpulan data juga dilakukan dengan studi dokumen yaitu berupa foto dan rekaman wawancara yang terkait dengan proses penelitian. Sukandarrumidi (2012) dokumentasi dapat berupa catatan pribadi, buku harian, laporan kerja, notulen rapat, catatan kasus, rekaman kaset, rekaman video, foto, dan lain sebagainya. Dokumentasi ini digunakan untuk tujuan penelitian, jadi penggunaannya harus selektif.

Studi pustaka diperlukan dalam pengumpulan data, karena mampu memperkuat keberadaan data yang didapat oleh peneliti. Menurut Haryanto (2000), studi pustaka merupakan karangan ilmiah yang berisi pendapat pakar tentang studi masalah, yang kemudiaan dibandingkan, ditelaah, dan ditarik kesimpulan. Peneliti sangat terbantu sekali terhadap keberadaan studi pustaka yang terdapat di perpustakaan pusat UGM, dan perpustakaan pasca sarjana. Peneliti disini juga menggunakan data online, data yang digunakan peneliti untuk melengkapi tesis ini. Menurut Nursalam (2008), online adalah perangkat yang memberikan keefisienan waktu dan kemudahan dalam mengerjakan sesuatu. Dalam proses pencarian data sekunder online sangat dibutuhkan peneliti untuk memahami sesuatu.

Strategi fenomenologi ini merupakan strategi penelitian yang didalamnya peneliti mengidentifikasi hakikat manusia tentang suatu fenomena tertentu (Creswell, 2009). Pendekatan fenomenologi mempunyai empat tahap, yaitu epoche, reduction, horizonalitation, dan Imaginative variation, maka penelitian tersebut harus melalui tahapan tersebut. Hasil pengumpulan data yang telah melalui tahapan pendekatan fenomenologi akan dianalisis menggunakan open coding awal, open coding akhir yang dikombinasikan dengan trianggulasi data, dan yang terakhir axial coding.

\section{Peran Konseling Panti Rehabilitasi Di Panti Sosial Pamardi Putra Yogyakarta}

Penanggulangan permasalahan pemuda korban narkoba melalui pelayanan terapi dan rehabilitasi di PSPP Yogyakarta sangat dipengaruhi oleh sumber daya manusia, yang mempunyai peranan penting dalam proses pemulihan residen melalui Therapeutic Community adalah konselor, yang kegiatan utamanya adalah konseling. Menurut Supriatna (2013), konselor adalah tenaga professional yang memiliki sertifikasi dan lisensi untuk menyelenggarakan layanan profesionalnya. Diketahui terdapat 26 konselor yang melakukan proses konseling di PSPP Yogyakarta. Seorang konselor di PSPP Yogyakarta dalam jabatan apapun tetap memiliki tanggung jawab untuk mampu melakukan pendekatan kepada residen (pecandu narkoba) melalui static konseling.

Menurut Kusmaryani (2010), suatu proses konseling adalah bantuan yang diberikan seseorang yang berprofesi di bidang konseling kepada induvidu yang memiliki masalah. Individu yang memiliki masalah ini di PSPP Yogyakarta disebut sebagai residen (pemuda penyalahgunaan narkoba) baik yang mendapatkan tindak pidana maupun yang 
Rusti Aisya Dilliana, Fathul Himam, Samsul Maarif -- Peran Konseling Panti Rehabilitasi Dalam Menangani Pemuda Korban Narkoba Dan Implikasinya Terhadap Ketahanan Pribadi (Studi Pada Panti Sosial Pamardi Putra, Sleman, Daerah Istimewa Yogyakarta)

dilaporkan masyarakat/ keluarga. Melalui observasi diketahui bahwa seluruh residen yang berada di PSPP Yogyakarta pada tahun 2016 ini meningkat dari 40 residen (dari bulan desember 2015 - febuari 2016) hingga 73 residen (dari bulan maret- juni 2016).Bentuk proses konseling ini disesuaikan dengan program Therapeutic Community, bertujuan untuk memahami residen, mempelajari dampak narkoba yang residen gunakan, dan menyemangati residen untuk mampu hidup lebih baik. Fungsi konseling dalam penelitian ini merupakan esensi (nilai) yang tersembunyi dari peran konseling. Fungsi konseling tersebut adalah fungsi konseling dalam menciptakan kenyamanan dan fungsi konseling sebagai Role Model. Fungsi konseling sebagai role model pun dibedakan ke dalam dua jenis yakni role model as parent (orang tua) dan role model as friend (teman).

Faktor konseling ini sangat mempengaruhi terciptanya sebuah konseling yang baik. Menurut Manuaba (2003), faktor konseling merupakan sesuatu yang dipandang dalam proses untuk mencari kesimpulan yang baik antara konselor dan konseli. Faktor konseling tersebut memiliki beberapa kategori, sebagaimana tabel 1.

Kendala di PSPP Yogyakarta ini adalah ancaman narkoba yang telah merajalela, sehingga harus dicari penanggulanggannya. Beberapa kendalanya adalah keterbatasan jumlah SDM, Jumlah residen yang bertambah banyak, tempat penampungan residen yang terbatas, pengamanan yang kurang, kurangnya buku tentang Counselor Drug Abuse, dan kurangnya permainan dalam program therapeutic Community.

Peneliti di sini mencoba menganalisis hasil dari wawancara tersebut menggunakan tahapan pendekatan fenomenologi dan diakhiri dengan open coding dan axial coding. Data primer sebelum dianalisis harus mencapai tahap imaginative variation, kemudian diolah peneliti dengan open coding awal (tabel 2), hingga mencapai open coding akhir

Tabel 1

Faktor Konseling

\begin{tabular}{|l|l|l|}
\hline \multicolumn{1}{|c|}{ Kriteria } & \multicolumn{1}{c|}{ Faktor Konseling } & Sub Faktor Konseling \\
\hline $\begin{array}{l}\text { Supporting } \\
\text { (Sandaran) }\end{array}$ & $\bullet$ Panutan Philosophy & $\bullet$ Honesty \\
\hline Empati & $\bullet \begin{array}{l}\text { Intuisi (Pintar dari Tuhan hingga mampu masuk } \\
\text { dalam situasi dan kondisi tertentu residen) }\end{array}$ & \\
\hline $\begin{array}{l}\text { Safe } \\
\text { (Terjaga) }\end{array}$ & $\bullet$ Positive Thinking & \\
\hline Sabar & $\bullet$ Open Residen's Mind & \\
\hline Inspirator & $\bullet$ Pendekatan Pengalaman & \\
\hline Kepedulian & $\bullet$ Pendekatan Ekspresi & \\
\hline Pembimbing & $\bullet$ Hypothetic Question & \\
\hline Problem Solving & $\bullet$ Keteladanan & Family Millieu \\
\hline Kecocokan & $\bullet$ Emotional and Psychology & \\
\hline Pemerhati & $\bullet$ Ulet & \\
\hline Kebersamaan & $\bullet$ Parents & \\
\hline Anthusias & $\bullet$ Pengobatan & \\
\hline
\end{tabular}

Sumber: Oleh Peneliti, 2016 
Tabel 2

Analisis Wawancara (Open Coding Awal)

\begin{tabular}{|c|c|c|c|}
\hline Tema & Subtema & Tema & Sub Tema \\
\hline Empati & \multirow[b]{2}{*}{$\begin{array}{l}\text { - } \text { Pendekatan pengalaman } \\
\text { - } \text { Pendekatan Pemahaman } \\
\text { - } \text { Peep Heart Approach } \\
\text { - Pendekatan Feeling } \\
\text { - Pendekatan Ekspresi } \\
\text { - Small talk (Prestasi/ Istimewa) } \\
\text { - Keibuan } \\
\text { - Good looking Penampilan } \\
\text { - Menarik } \\
\text { - Pacana Hukum (Persidangan) }\end{array}$} & & \\
\hline $\begin{array}{l}\text { Tema empati ini didapatkan melalui } \\
\text { analisis sikap konselor dalam } \\
\text { melakukan pendekatan ini. Menurut } \\
\text { Sumartono (2004), Empati adalah } \\
\text { kemampuan memahami diri orang } \\
\text { lain, hingga seperti menjadi diri orang } \\
\text { lain tersebut. Kemampuan ini mampu } \\
\text { membaca pemikiran seseorang } \\
\text { melalui sudut pandang orang lain. } \\
\text { Pemahaman yang mendalam tentang } \\
\text { seseorang mampu dilakukan dengan } \\
\text { sifat empati ini. }\end{array}$ & & & \\
\hline Ketahanan Pribadi & \multirow[b]{2}{*}{ 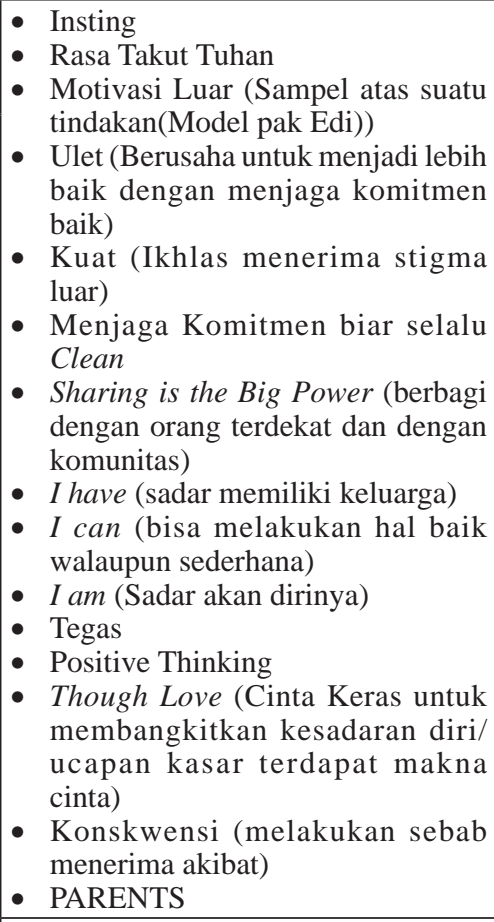 } & \multirow[t]{2}{*}{ Parents } & \multirow{2}{*}{$\begin{array}{l}\text { - } \text { Mediator } \\
\text { - } \text { Pendekatan FOTO } \\
\text { - Family Mllieu Concept } \\
\text { - Family Support Group } \\
\text { - Relationship }\end{array}$} \\
\hline $\begin{array}{l}\text { TemaKetahanan Pribadi ini, digunakan } \\
\text { peneliti untuk memunculkan keuletan } \\
\text { dan ketangguhan dalam diri residen. } \\
\text { Sikap ini dimunculkan untuk } \\
\text { memulihkan kondisi residen, dan } \\
\text { membentuk komitmen clean drug. } \\
\text { S o edars o n o (1997), fakt or } \\
\text { seseorang yang memiliki ketahanan } \\
\text { pribadi adalah, sebagai berikut: } \\
\text { (1) Memiliki rasa percaya diri dan } \\
\text { berpegang pada prinsip, (2) Bebas } \\
\text { dari rasa ketergantungan, namun } \\
\text { mendambakan kebersamaan, (3) } \\
\text { Memiliki jiwa dinamis, kreatif, } \\
\text { dan pantang menyerah. Penjelasan } \\
\text { Soedarsono tersebut merupakan } \\
\text { implikasi yang dimunculkan dari } \\
\text { penanaman nilai-nilai ketahanan } \\
\text { pribadi. }\end{array}$ & & & \\
\hline \multirow{2}{*}{$\begin{array}{l}\text { Problem Solving } \\
\text { Tema ini merupakan salah satu } \\
\text { strategi konselor untuk menyelesaikan } \\
\text { masalah residen, keputusan di sini } \\
\text { memang ditangan residen namun } \\
\text { memberikan caraalternatif merupakan } \\
\text { fungsi konseling juga. Menurut } \\
\text { Geldard (2011), fungsi konseling } \\
\text { yang utama adalah pembangunan } \\
\text { hubungan, pembangunan masalah, } \\
\text { dan penyelesaian masalah. Hal } \\
\text { ini memacu konselor untuk } \\
\text { memberikan pendekatan khusus } \\
\text { dalam berkonseling dengan residen, } \\
\text { agar residen lebih tenang dan beban } \\
\text { masalahnya berkurang. }\end{array}$} & \multirow{2}{*}{$\begin{array}{ll}\text { - } & \text { Pendekatan Imajinasi } \\
\text { - } & \text { Oranggung Jawab (kantor dan } \\
\text { - } & \text { Role Model } \\
\text { - } & \text { Arahan Open Residen's Mind } \\
\text { - Emotional Psycology } \\
\text { - } \text { Punishment } \\
\text { - Keteladanan } \\
\text { - Key and Counselling }\end{array}$} & $\begin{array}{l}\text { Key and } \\
\text { Counseling }\end{array}$ & $\begin{array}{ll}\text { - } & \text { Aman terjaga Rahasianya } \\
\text { - } & \text { Dianaman (sebagai anak, adek, } \\
\text { - } & \text { Cinta (Konselor mencintai } \\
& \text { Residen) } \\
\text { - } & \text { Mencintai (Residen } \\
& \text { Mencintai Konselor) }\end{array}$ \\
\hline & & $\begin{array}{l}\text { Cinta, } \\
\text { Mencintai }\end{array}$ & $\begin{array}{ll}\text { - } & \text { Belajar Perilaku Baik } \\
\text { - } & \text { Tensenyupa } \\
\text { - } & \text { Mengetuk Pintu (Sopan) } \\
\text { - } & \text { Menghargai } \\
\text { - } & \text { Merja dengan hati } \\
\text { - Niakukan dengan sadar diri } \\
\text { - } \\
\text { - Using Humor } \\
\text { - } & \text { Pendengar Aktif } \\
\end{array}$ \\
\hline
\end{tabular}


Rusti Aisya Dilliana, Fathul Himam, Samsul Maarif -- Peran Konseling Panti Rehabilitasi Dalam Menangani Pemuda Korban Narkoba Dan Implikasinya Terhadap Ketahanan Pribadi

(Studi Pada Panti Sosial Pamardi Putra, Sleman, Daerah Istimewa Yogyakarta)

sambungan dari tabel 2 halaman 346

\begin{tabular}{|c|c|c|c|}
\hline & & $\begin{array}{l}\text { Aman, } \\
\text { Nyaman }\end{array}$ & $\begin{array}{ll} & \text { Rahasia Terjaga } \\
\text { - Sebagai teman } \\
\text { - Sebagai Bapak } \\
\text { - } \text { Menemani dipersidangan } \\
\text { - Engagement } \\
\text { - } \text { Encourage } \\
\text { - } \text { Feexing Regularly } \\
& \text { Character }\end{array}$ \\
\hline \multirow{2}{*}{$\begin{array}{l}\text { Recovery } \\
\text { Recovery merupakan tema yang } \\
\text { bertujuan mengobati residen } \\
\text { dengan pelayanan dan perawatan } \\
\text { rehabilitasi. Mengingat seorang } \\
\text { pecandu memiliki efek dari narkoba } \\
\text { yang digunakannya. Diketahui } \\
\text { melalui data yang didapatkan } \\
\text { peneliti di PSPP Yogyakarta, } \\
\text { bahwa pengobatan menggunakan } \\
\text { Therapeutic Community ada empat. } \\
\text { Salah satu konselor menerangkan } \\
\text { bahwa yang digunakan hanya satu, } \\
\text { yaitu Cold Turkey. }\end{array}$} & \multirow{2}{*}{$\begin{array}{l}\text { - } \text { Pengobatan } \\
\text { - } \text { Ikhlas } \\
\text { - Hypothetic Question } \\
\text { - Komitmen } \\
\text { - Sabar } \\
\text { - Insting } \\
\text { - Kesadaran Diri } \\
\text { - Disiplin } \\
\text { - PANUTAN PHILOSOPHY } \\
\text { - } \text { Love, Concern, and Responsible }\end{array}$} & Progress & $\begin{array}{l}\text { - Teliti } \\
\text { - Tekad Besar } \\
\text { - Komitmen } \\
\text { - Sequencing } \\
\text { - } \text { Observasi } \\
\text { - Neliti } \\
\text { - Nasehat } \\
\text { - Jujur }\end{array}$ \\
\hline & & $\begin{array}{l}\text { Panutan } \\
\text { Philosophy }\end{array}$ & $\begin{array}{l}\text { - Jujur Honesty } \\
\text { - Harga Diri } \\
\text { - To be Aware is to be alive } \\
\text { - } \text { Forgiveness } \\
\text { Presure and Hard }\end{array}$ \\
\hline
\end{tabular}

Sumber : Hasil Olahan Peneliti, 2016

Tabel 3

Analisis Wawancara (Open Coding Akhir)

\begin{tabular}{|c|c|c|c|c|}
\hline Fungsi Konseling & Sub Fungsi & Kriteria & Faktor Konseling & Turunan Faktor Konseling \\
\hline \multirow{5}{*}{$\begin{array}{l}\text { KENYAMANAN } \\
(B L E N D F I T)\end{array}$} & & Empati & $\begin{array}{ll}\text { - } & \text { Small Talk (Prestasi) } \\
\text { - } & \text { Keibuan } \\
\text { - } & \text { Wacan Heart Approach } \\
\text { - } & \text { Pendekatan Feeling } \\
\text { - } & \text { Intuisi (Pintar dari Tuhan hingga } \\
& \text { mampu masuk dalam situasi dan } \\
& \text { kondisi tertentu) }\end{array}$ & \\
\hline & & $\begin{array}{l}\text { Safe } \\
\text { (Terjaga) }\end{array}$ & $\begin{array}{ll}\text { - } & \text { Rasa Takut Tuhan } \\
\text { - } & \text { Cleanjaga Komitmen biar selalu } \\
\text { - Sharing is Big Power } \\
\text { - } \text { Positive Thinking } \\
\text { - Konskwensi } \\
\text { - Parents } \\
\end{array}$ & - Relationship \\
\hline & & Sabar & $\begin{array}{l}\text { - } \text { Pendekatan Imajinasi } \\
\text { - } \text { Open Residen's Mind } \\
\text { - Key and Counseling }\end{array}$ & $\begin{array}{l}\text { - Aman terjaga rahasianya } \\
\text { - Nyaman } \\
\text { - Cinta } \\
\text { - Mencintai } \\
\end{array}$ \\
\hline & & $\begin{array}{l}\text { Supporting } \\
\text { (Sandaran) }\end{array}$ & - Progress & - Sequencing \\
\hline & & & - Panutan Philosophy & $\begin{array}{l}\text { - Honesty } \\
\text { - } \quad \text { To be Aware is to be alive }\end{array}$ \\
\hline \multirow[t]{2}{*}{$\begin{array}{c}\text { PANUTAN (ROLE } \\
\text { MODEL) }\end{array}$} & $\begin{array}{l}\text { ORANG } \\
\text { TUA }\end{array}$ & Inspirator & $\begin{array}{ll}\text { - } & \text { Pendekatan Pengalaman } \\
\text { - } & \text { Gondekatan Non Verbal } \\
\end{array}$ & \\
\hline & & Pemerhati & $\begin{array}{l}\text { - Insting } \\
\text { - Ulet } \\
\text { - Tangguh } \\
\text { - Tegas } \\
\text { - I am, I have, and I can } \\
\text { - Though Love } \\
\text { - Parents }\end{array}$ & $\begin{array}{ll}\text { - } & \text { Mediator } \\
\text { - } & \text { Pendekatan FOTO }\end{array}$ \\
\hline
\end{tabular}

bersambung ke halaman 348 
sambungan dari tabel 3 halaman 347

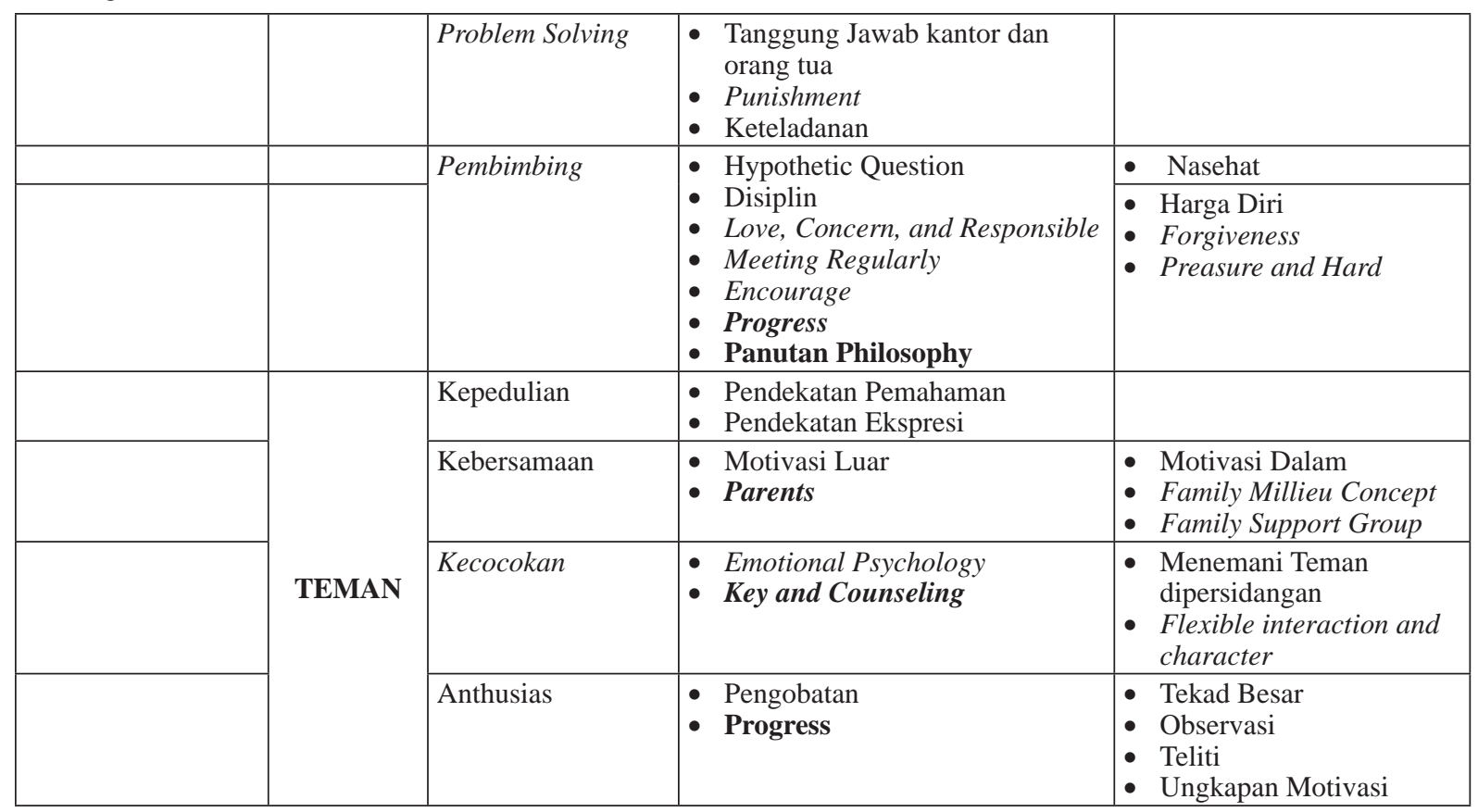

Sumber: Olahan Peneliti, 2016

Tabel 4

Axial Coding

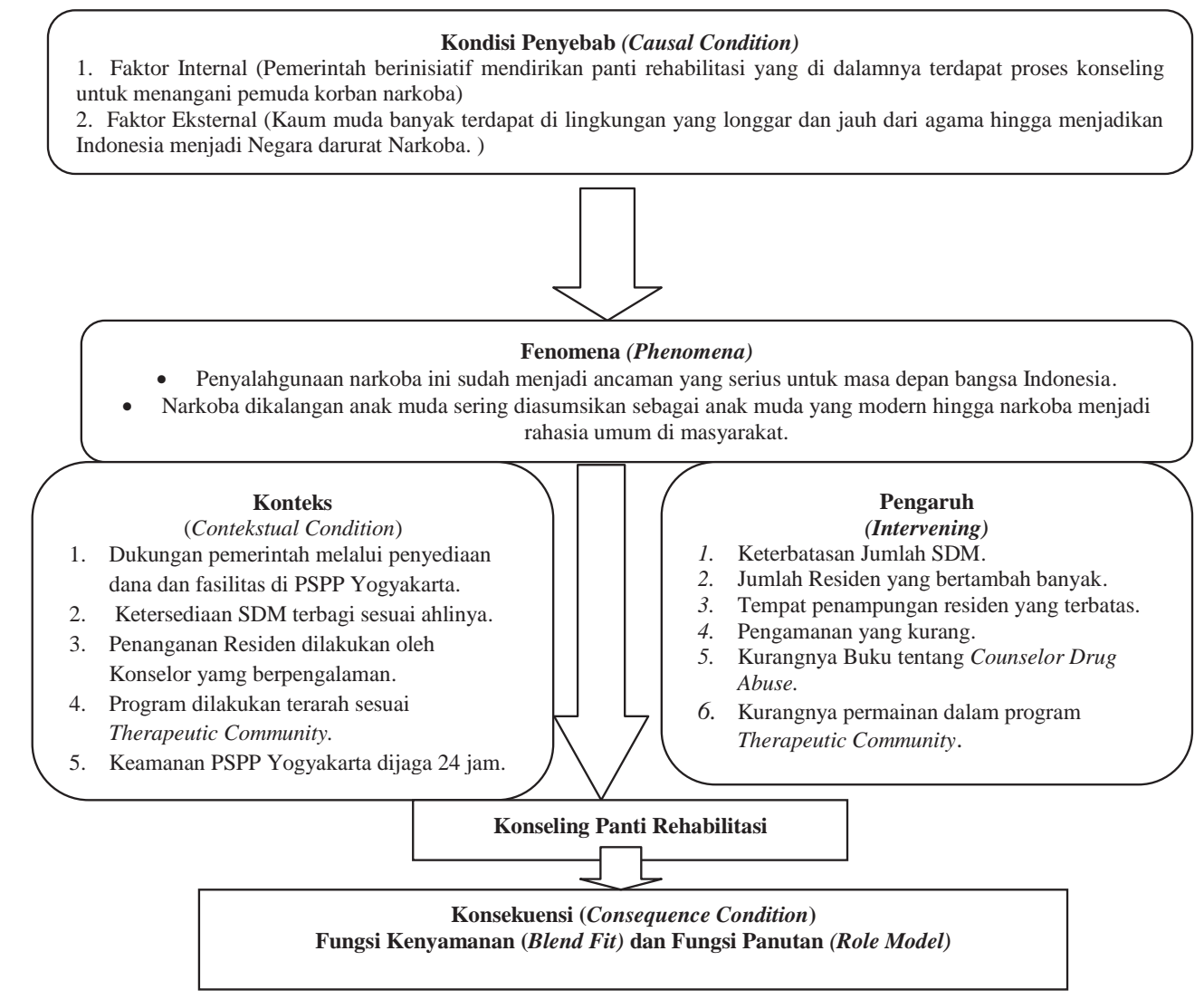

Sumber :Olahan Peneliti, 2016 
Rusti Aisya Dilliana, Fathul Himam, Samsul Maarif -- Peran Konseling Panti Rehabilitasi Dalam Menangani Pemuda Korban Narkoba Dan Implikasinya Terhadap Ketahanan Pribadi

(Studi Pada Panti Sosial Pamardi Putra, Sleman, Daerah Istimewa Yogyakarta)

Tabel 5

Hasil Peran Konseling

\begin{tabular}{|c|c|c|}
\hline Konseling & Hasil & $\begin{array}{l}\text { BerImplikasi Ketahanan } \\
\text { Pribadi Sesuai Pakar Ahli }\end{array}$ \\
\hline $\begin{array}{l}\text { a) Small Talk (Prestasi) } \\
\text { b) Progress (Ungkapan Motivasi) } \\
\text { c) Pendekatan Imajinasi } \\
\text { d) Love, Concern, and Responsible } \\
\text { e) Panutan Phylosophy } \\
\text { 1. Harga Diri } \\
\text { 2. Forgiveness } \\
\text { 3. Preasure and Hard } \\
\text { f) Key and Counseling (Aman } \\
\text { terjaga rahasianya, Nyaman, Cinta, } \\
\text { Mencintai) } \\
\text { g) Pendekatan Feeling } \\
\text { h) Intuisi (Pintar dari Tuhan hingga } \\
\text { mampu masuk dalam situasi dan } \\
\text { kondisi tertentu) } \\
\text { i) Sharing is the big power. } \\
\text { j) Progress (Sequencing) } \\
\text { k) Panutan Philosophy (To be Aware is } \\
\text { to be alive) } \\
\text { l) Konsekwensi } \\
\text { m) Good Looking } \\
\text { n) Ulet } \\
\text { o) Tangguh } \\
\text { p) Insthing } \\
\text { q) Parents } \\
\text { r) Panutan Philosophy (Honesty) } \\
\text { s) Punishment } \\
\text { t) Keteladanan } \\
\text { u) Encourage } \\
\text { v) Emotional Psychology } \\
\text { w) Pengobatan } \\
\text { x) Tekad Besar } \\
\text { y) Observasi } \\
\text { z) Teliti } \\
\end{array}$ & $\begin{array}{l}\text { a) Percaya Diri } \\
\text { b) Mengaktualisasikan diri dengan rasa percaya diri } \\
\text { Berusaha berimajinasi tanpa shabu. } \\
\text { c) Berperilaku teratur, dan memanagemen waktu. } \\
\text { d) Residen mempunyai tekad besar untuk pulih. } \\
\text { 1. Residen belajar untuk berbuat baik sesuai } \\
\quad \text { aturan } \\
\text { 2. Berpola hidup sehat, control emosi dan tidak } \\
\quad \text { menyakiti siapapun. } \\
\text { 3. Berperilaku sopan } \\
\text { e) Jujur } \\
\text { f) Sopan, dan niat baik muncul. } \\
\text { g) Emosi residen terkendali. } \\
\text { h) Residen akan mulai terbuka untuk mengurangi } \\
\text { bebannya. } \\
\text { i) berusaha belajar materi rehabilitasi untuk pulih. } \\
\text { j) Mampu berbuat baik untuk lingkungan dan } \\
\text { sesama. } \\
\text { k) Residen akan berhati-hati dalam bersikap. } \\
\text { l) berusaha hidup rapi dan bersih. } \\
\text { m) Sikap tangguh dalam merngambil keputusan. } \\
\text { n) Tidak mudah menyerah. } \\
\text { o) Berusaha untuk Clean } \\
\text { p) Membuat keluarga tenang } \\
\text { q) Perubahan baik melalui hal kecil } \\
\text { r) Melakukan hal baik } \\
\text { s) Melakukan hal baik tanpa paksaan } \\
\text { t) Residen punya tekad untuk pulih } \\
\text { u) Kontrol Emosi } \\
\text { v) niat baik, clean drug, kerja keras, jujur, dan } \\
\text { ikhlas } \\
\text { w) Mengaktualisasikan diri. } \\
\text { x) Mudah pulih } \\
\text { y) Punya tekad besar }\end{array}$ & $\begin{array}{ll}\text { - } & \text { Soedarsono (1997) } \\
\text { - } & \text { Widuri (2012) } \\
\text { - } & \text { Oktaviana (2013) } \\
\text { - } & \text { DeLameter (2006) } \\
\text { - } & \text { Sunardi (2005) } \\
\text { - } & \text { Sukino (2013) } \\
\text { - } & \text { Hariyanto (2009) }\end{array}$ \\
\hline $\begin{array}{l}\text { - Wacana Hukum (Persidangan) } \\
\text { - Open Residen’s Mind } \\
\text { - Positive Thinking } \\
\text { - Hypothethic Question } \\
\text { - Disiplin } \\
\text { - Motivasi Luar } \\
\text { - Family Support Group }\end{array}$ & $\begin{array}{l}\text { - Kepastian Hukum } \\
\text { - Residen bisa mengambil keputusan baik } \\
\text { - Residen tidak mudah kecewa. } \\
\text { - Menghindari perilaku yang tidak baik } \\
\text { - Mampu memanagement waktu } \\
\text { - Komitmen/ Prinsip } \\
\text { - Sadar memiliki keluarga. }\end{array}$ & Hardiyani (2015) \\
\hline $\begin{array}{l}\text { - Rasa Takut Tuhan } \\
\text { - Menjaga Komitmen biar selalu } \\
\text { Clean } \\
\text { - I am, I have, and I can } \\
\text { - Parents (Pendekatan foto) }\end{array}$ & $\begin{array}{l}\text { - Memahami keagungan Tuhan } \\
\text { - Terjaga Clean Drug } \\
\text { - Bersyukur dengan apa yang residen miliki } \\
\text { - Syukur atas adanya keluarga }\end{array}$ & $\begin{array}{ll}\text { - } & \text { Grotberg (1995) } \\
\text { - } & \text { Muhdi (2011) }\end{array}$ \\
\hline $\begin{array}{l}\text { - Progress (nasehat) } \\
\text { - Pendekatan Ekspresi }\end{array}$ & $\begin{array}{l}\text { - Residen belajar untuk baik } \\
\text { - Mempermudah residen belajar Coping Skill }\end{array}$ & $\begin{array}{l}\text { Sunardi (2005) } \\
\text { Ghani (2013) }\end{array}$ \\
\hline
\end{tabular}

bersambung ke halaman 350 
sambungan dari tabel 5 halaman 349

\begin{tabular}{|c|c|c|}
\hline $\begin{array}{l}\text { - } \text { Keibuan } \\
\text { - } \text { Deep Heart Approach } \\
\text { - } \text { Pendekatan Non Verbal } \\
\text { - Tegas Love } \\
\text { - } \text { Parents (Mediator) } \\
\text { - Tanggung Jawab kantor dan orang } \\
\text { - } \text { Mea } \\
\text { - } \text { Pendekatang Regularly } \\
\text { - } \text { Family Millieu Concept } \\
\text { - } \text { Menemani Teman dipersidangan } \\
\text { - Flexible interaction and character }\end{array}$ & $\begin{array}{l}\text { - Residen merasa terlindungi dalam masalah. } \\
\text { - Residen merasa tenang. } \\
\text { - Residen dimengerti konselor } \\
\text { - Residen merasa dicintai konselor } \\
\text { - } \text { Mempunyai panutan yang bijaksana. } \\
\text { - Herasa dilindungi } \\
\text { - Residen lebih akrab dengan konselor } \\
\text { - Residen merasa dimengerti } \\
\text { - Nyaman di PSPP } \\
\text { - Terlindungi dipersidangan } \\
\text { - Residen dan konselor akan mudah saling } \\
\text { memahami }\end{array}$ & $\begin{array}{l}\text { Tidak sesuai dengan implikasi } \\
\text { ketahanan pribadi }\end{array}$ \\
\hline
\end{tabular}

Sumber: Olahan Peneliti, 2016

Tabel 6

Indikator Ketahanan Pribadi

\begin{tabular}{|c|c|}
\hline Pakar Ahli & Indikator Ketahanan Pribadi \\
\hline $\begin{array}{l}\text { Soedarsono (1997) } \\
\text { Soedarsono (1997) } \\
\text { Widuri (2012) } \\
\text { DeLameter (2006) } \\
\text { Oktaviana (2013) } \\
\text { Sunardi (2005) } \\
\text { Sukino (2013) }\end{array}$ & $\begin{array}{l}\text { - Faktor ketahanan pribadi } \\
\text { 1. Memiliki rasa percaya diri dan berpegang teguh pada prinsip. } \\
\text { 2. Bebas dari rasa ketergantungan, namun mendambakan kebersamaan. } \\
\text { 3. Memiliki jiwa dinamis, kreatif, dan pantang menyerah. }\end{array}$ \\
\hline Muhdi (2011) & - Mau menerima diri sendiri walaupun tidak ada kesempurnaan. \\
\hline Grotberg (1995) & - Faktor utama ketahanan pribadi adalah I have, I am, dan I can. \\
\hline Ghani (2013) & - Pendidikan membangun ketahanan pribadi. \\
\hline Sunardi (2005) & - Profesionalisme dipengaruhi tingkat pengetahuannya. \\
\hline Hardiyani (2015) & $\begin{array}{l}\text { Konsep menuntun keberhasilan dan kegagalan seseorang dalam menghadapi masalah } \\
\text { 1. Mampu mengenali dampak dan konsekwensi dari emosi dan perilaku yang } \\
\text { dilakukan. } \\
\text { 2. Mampu membangun kesadaran. } \\
\text { 3. Menemukan cara untuk bangkit dari keterpurukan. } \\
\text { 4. Menumbuhkan keyakinan. } \\
\text { 5. Mengurangi pemikiran negative. } \\
\text { 6. Mengutamakan kecepatan tanpa memperkirakan ketersediaan waktu. }\end{array}$ \\
\hline
\end{tabular}

Sumber: Olahan Peneliti, 2016

(tabel 3). Hasil dari open coding peneliti menyederhanakan dan mengembangkannya secara textual menjadi axial coding (tabel 4).

\section{Implikasinya Terhadap Ketahanan Pribadi Pemuda Korban Narkoba}

Proses konseling dilakukan untuk membentuk komitmen residen untuk pulih dan clean drug, residen sudah mampu memiliki keinginan untuk menciptakan cita-citanya dengan keuletan. Implikasi ketahanan pribadi peneliti dapatkan melalui analisis semua hasil konseling yang disesuai dengan indikator ketahanan pribadi, agar mampu mendapatkan hasil bahwa terdapat beberapa pendekatan yang dilakukan koselor berimplikasi terhadap peningkatan ketahanan pribadi dan ada yang 
Rusti Aisya Dilliana, Fathul Himam, Samsul Maarif -- Peran Konseling Panti Rehabilitasi Dalam Menangani Pemuda Korban Narkoba Dan Implikasinya Terhadap Ketahanan Pribadi (Studi Pada Panti Sosial Pamardi Putra, Sleman, Daerah Istimewa Yogyakarta)

tidak berimplikasi terhadap peningkatan ketahanan pribadi. Beberapa rincian hasil peran konseling dalam menangani pemuda korban narkoba di PSPP Yogyakarta, tampak pada tabel 5.

Dari tabel 5 diketahui terdapat hasil konseling yang berimplikasi terhadap peningkatan ketahanan pribadi dan yang tidak berimplikasi terhadap peningkatan ketahanan pribadi. Hal itu dikarenakan peneliti menyesuaikan dengan indikator dari ketahanan pribadi yang telah dijelaskan pada landasan teori. Indikator ketahanan pribadi tersebut diterangkan melalui tabel 6 di bawah ini.

Melalui tabel 6 tersebut peneliti menjelaskan keterangan tentang hasil peran konseling yang peneliti temukan dari penelitian dan kemudiaan diujikan dengan berbagai referensi landasan teori tentang ketahanan pribadi yang telah peneliti rumuskan. Dalam hal ini peneliti juga akan menjelaskan lebih rinci dengan mengambil beberapa pendekatan yang berimplikasi dengan ketahanan pribadi.

Pertama, small talk. Praktek dari Small Talk, adalah konselor mengungkapkan katakata kecil untuk mengistimewakan residen, sehingga mampu melahirkan perasaan nyaman residen untuk berinteraksi dan berkonsultasi dengan konselor, bahkan mampu memunculkan percaya diri seorang residen. Pernyataan tersebut sesuai dengan pernyataan ini, faktor seseorang yang memiliki ketahanan pribadi adalah memiliki rasa percaya diri dan berpegang pada prinsip (Soedarsono, 1997).

Kedua, konsekwensi. Praktek dari pendekatan konsekwensi ini sendiri adalah perbuatan salah yang dilakukan pasti akan ada akibat dan karmanya. Konselor di sini mengajarkan residen untuk memahami konsekwensi dari penggunaan narkoba yang dipakainya. Hasil dari pendekatan ini adalah residen akan mampu berhati-hati dalam bertindak. Hal ini sesuai dengan pernyataan yang diungkapkan oleh Oktaviana (2013). Pengembangan resiliensi merupakan dilakukan melalui perjalanan pribadi tiap individu dengan mampu menyikapi kondisi kehidupan dengan positif (Oktaviana, 2013).

\section{SIMPULAN}

Berdasar uraian tersebut di atas dapat ditarik simpulan sebagai berikut.

Pertama, peran konseling yang dilakukan konselor menghasilkan temuan penelitian berupa fungsi konseling. Fungsi konseling tersebut adalah fungsi konseling dalam menciptakan kenyamanan dan fungsi konseling sebagai role model, namun untuk fungsi konseling sebagai role model dibagi menjadi dua jenis yaitu fungsi konselor sebagai orang tua dan fungsi konselor sebagai teman. Diketahui bahwa fungsi konseling tersebut dilahirkan melalui hasil olahan penelitian dengan faktor konseling. Faktor konseling tersebut adalah, intuisi, sharing is big power, open mind, progress, panutan philosophy, pendekatan pengalaman, ulet, keteladanan, hypothetic question, pendekatan ekspresi, family milieu concept, emotional psychology, dan pengobatan cold turkey. Peneliti di sini juga menjelaskan beberapa kendala yang terjadi dalam proses konseling yang berlangsung tersebut.

Kedua, faktor konseling mampu menjelaskan implikasi peran konseling terhadap ketahanan pribadi. Indikator ketahanan pribadi harus mampu sesuai dengan hasil yang didapatkan oleh setiap praktek dari faktor konseling. 


\section{DAFTAR PUSTAKA}

Afdjani, H, 2010, “Makna Iklan Televisi (Studi Fenomenologi Pemirsa di Jakarta terhadap Iklan Televisi Minuman "Kuku Bima Energi” Versi Kolam Susu)”, Jurnal Ilmu Komunikasi, 8 (1), hlm 96-108.

Al-Ghifari, A, 2002, Generasi Narkoba, Bandung, Mujahid.

Ali, M.A.P., \& Duse, I, 2007, Narkoba Ancaman Generasi Muda, Kaltim, Gerpana.

Amal, I., \& Armawi, A., 1999, Keterbukaan Informasi dan Ketahanan Nasional, Yogyakarta, Gadjah Mada University Press.

Arief, R, 2008, “Analisis Proses Internal Rehabilitas Sosial Unit Pelaksana Teknis Terapi dan Rehabilitasi Badan Narkotika Nasional”, Tesis: Universitas Indonesia.

BNN DIY, 2012, Data Tindak Pidana Narkoba Provinsi Daerah Istimewa Yogyakarta, <http://www.bnn.go.id/portal/_ uploads/post/2012/05/10/2012051016560510243.pdf> (diakses 8 Desember 2015).

BNN RI, 2015, Panduan Pemberdayaan Sekolah Bebas Narkoba (PSBN), Yogyakarta, Badan Narkotika Nasional Perovinsi Daerah Istimewa Yogyakarta.

Creswell, J. W, 2009, Research Design: Qualitative, Quantitative, and Mixed Methods Approach (third edition), Thousand Oaks, CA, Sage.

Creswell, J. W., 2013, Qualitative Inquary \& Research Desaign: Choosing Among Five Approaches (third edition), Thousand Oaks, CA: Sage.

DeLamater, J., 2006, Handbook of Social Psycology, Madison, Springer.

Diniaty, A., 2013, “Urgensi Teori Konseling dan Perspektifnya dalam Islam Menjawab Tuntutan Konseling Religius di Masa
Depan”, Jurnal Al-Ta'lim, 1(4), hlm. 312323.

Geldard, K, \& Geldard, D., 2011, Konseling Remaja: Pendekatan Proaktif untuk Anak Muda, Yogyakarta, Pustaka Pelajar.

Ghani,A, 2013, "Peran Pondok Pesantren dalam Membangun Karakter Generasi Muda dan Implikasinya terhadap Ketahanan Pribadi (Studi di Pondok Pesantren Jamiyyah Islamiyah Ceger Kelurahan Jurang Mangu Timur Kecamatan Pondok Area Kota Tangerang Selatan Provinsi Banten)”,Tesis, Universitas Gadjah Mada.

Grotberg, 1995, “A Guide to Promoting Resilience in Children: Strengthening the Human Spirit. The Series Early Childhood Development: Practice and Reflections. Bernard Van Leer Foundation”, (8), hal 1-39.

Gunarsa, S.D., 2007, Konseling dan Psikoterapi, Jakarta, PT. BPK Gunung Mulia.

Hardiyani, S. P., 2015, "Resiliensi pada Orang dengan HIV/ AIDS”, Universitas Semarang, hal. 278-285.

Haryanto, Ruslijanto, H.,\& Mulyono, D.,2000, Metode Penulisan dan Penyajian Karya Ilmiah: Buku Ajar untuk Mahasiswa, Jakarta, Buku Kedokteran EGC.

Hariyanto, S, 2009, "Perilaku Membolos Mempengaruhi Ketahanan Pribadi: Studi Kasus di 3 SLTA Negeri Magelang”, Tesis, Universitas Gadjah Mada.

Hesse, S. N., 2010, The Practice of Qualitative Research, Los Angles, Sage Publication. Humeira, Yulia, \& Sutarno, 2014, "Keefektifan Layanan Bimbingan Kelompok dengan Tehnik Bermain Peran untuk Meningkatkan Efikasi Diri dalam Belajar”, Jurnal FKIP Universitas Sebelas Maret, hlm 1-9. 
Rusti Aisya Dilliana, Fathul Himam, Samsul Maarif -- Peran Konseling Panti Rehabilitasi Dalam Menangani Pemuda Korban Narkoba Dan Implikasinya Terhadap Ketahanan Pribadi (Studi Pada Panti Sosial Pamardi Putra, Sleman, Daerah Istimewa Yogyakarta)

Joewana, S., 2006, Peran Orang Tua dalam Mencegah dan Menanggulangi Penyalahgunaan Narkoba, Jakarta, PT. Balai Pustaka.

Kusmaryani, E. R., 2010, "Penguasaan Keterampilan Konseling Guru Pembimbing di Yogyakarta”, Jurnal Kependidikan, 40(2), hal 175-188.

Liliweri, A., 2003, Makna Budaya dalam Komunikasi Antar Budaya, Yogyakarta, PT. LkiS Pelangi Aksara.

Manuaba, M, C., \& Manuaba, F., 2003, Pengantar Kuliah Obstetri, Jakarta, Buku Kedokteran EGC.

Muhdi, 2011, Pendidikan dan Latihan Profesi Guru (PLPG) Sertifikasi Dalam Jabatan; Bimbingan Konseling, Semarang: Panitia Sertifikasi Guru Rayon 39 IKIP PGRI Semarang 2011.

Nursalam \& Efendi, F, 2008, Pendidikan dalam Keperawatan, Jakarta, Salemba Medika.

Oetami, A., 2014, Buku Panduan: Pencegahan dan Penanggulangan Penyalahgunaan Narkoba, Yogyakarta, Dinas Kesehatan Daerah Istimewa Yogyakarta.

Oktaviana, A., 2013, “The Correlation between Locus of Control and Social Suport Resillience in Adolescents with Deaf Disable”, University of Mulawarman Journal, hal 1-8.

PSPP DIY, 2015, Dinas Sosial Daerah Istimewa Yogyakarta Panti Sosial Pamardi Putra Yogyakarta (Brosur), Yogyakarta, Panti Sosial Pamardi Putra Yogyakarta.

Soedarsono, S., 1997, Ketahanan Pribadi \& Ketahanan Keluarga; Sebagai Tumpuan
Ketahanan Nasilonal, Jakarta, PT. Intermasa.

Stea, J.N., Yakovenko, I, \& Hodgins, D.C., 2015, Recovery from Cannabis Use Disorder: Abstinence Versus Moderation and Treatment-Assisted Recovery Versus Natural Recovery, Vol. 29 (3), hal.522531.

Sukandarrumidi, 2012, Metodelogi Penelitian: Petunjuk Praktis untuk Peneliti Pemula, Yogyakarta, Gadjah Mada University Press.

Sunardi, RM, 2005, Pembinaan Kebangsaan Indonesia: Dalam Rangka Menjaga Integritas Negara bdan Pembentukkan Jati Diri Bangsa, Jakarta, PT. Kuartentika Adidama.

Supriatna,M., 2013, Bimbingan dan Konseling Berbasis Kompetensi, Jakarta, PT. Raja Grafindo Persada.

Yeo, A., 2007, Konseling: Suatu Pendekatan Pemecahan Masalah, Jakarta, Gunung Mulia.

\section{Peraturan Perundangan}

UU Nomor 5 Tahun 1997 tentang Psikotropika

UU Nomor 22 Tahun 1997 tentang Narkotika

UU Nomor 11 Tahun 2009 tentang Kesejahteraan Sosial

UU Nomor 35 Tahun 2009 tentang Narkotika

\section{Wawancara}

1. Rama pada 25 November 2015 